\title{
Unexpected detection of Plasmodium vivax and Plasmodium falciparum DNA in asymptomatic blood donors: fact or artifact?
}

\author{
Alfredo Mendrone $\mathrm{Jr}^{1}$, Crispim Cerutti $\mathrm{Jr}^{2}$, José Eduardo Levi ${ }^{14^{*}}$, Marcos Boulos ${ }^{3}$, Maria Carmen Arroyo Sanchez ${ }^{4}$, \\ Rosely dos Santos Malafronte ${ }^{4}$, Silvia Maria Di Santi ${ }^{4,5}$ and Vicente Odone $\mathrm{Jr}^{1}$
}

\begin{abstract}
A study searching for Plasmodium vivax and Plasmodium falciparum DNA among blood donors from the non-endemic area in Brazil reported a rate of $7.41 \%$. This number is at least three times higher than what has been observed in blood donors from the Amazon, an endemic area concentrating $>99 \%$ of all malaria cases in Brazil. Moreover, the majority of the donors were supposedly infected by $P$. falciparum, a rare finding both in men and anophelines from the Atlantic forest. These findings shall be taken with caution since they disagree with several publications in the literature and possibly overestimate the actual risk of malaria transmission by blood transfusion in São Paulo city.
\end{abstract}

\section{Background}

The recently published article from Maselli et al. [1] presents results and conclusions that shall be taken with caution, despite their sound and robust analytical method. In their article, the epidemiological knowledge of the "bromeliad-malaria" $[2,3]$ should have been taken into account. During the 1960s, malaria of simians was studied [4,5] and, in Atlantic Forest, anophelines of the subgenus Kerteszia were incriminated as vectors of the two species of parasites considered equivalent to Plasmodium vivax and Plasmodium malariae. In contrast, Plasmodium falciparum was never detected in simians from the Atlantic Forest of the city of São Paulo [6]. Curiously, Maselli and co-workers state in the discussion that "In the Atlantic Forest, Alouatta monkeys have been found to be infected by P. vivax and P. malariae [ref49], along with P. falciparum [ref48]". However, the cited work [7] does not involve any monkey sample and, in fact, previous studies on natural infection of anophelines from the Atlantic Forest of the states of São Paulo and Espírito Santo showed no P. falciparum infections in Kersteszia or Nyssorhynchus subgenus. Only P. vivax and $P$. malariae infections were detected [7-9]. Over the

\footnotetext{
* Correspondence: jelevi@prosangue.sp.gov.br

${ }^{1}$ Fundação Pró-Sangue, Hemocentro de São Paulo, São Paulo, Brazil

${ }^{4}$ Instituto de Medicina Tropical, Universidade de São Paulo, São Paulo, Brazil Full list of author information is available at the end of the article
}

last two decades, several studies focused on various aspects of "bromeliad" malaria transmission [10,11]. In some of those investigations, DNA supposed to be from P. falciparum was also amplified [10], but it did not usually resist to a second amplification by another method. Sometimes, the second amplification disclosed P. malariae, instead.

So far there are only two published studies investigating Plasmodium prevalence by molecular methods among Brazilian blood donors [12,13], both performed in the endemic area (the Amazon) and cited in the paper of Maselli et al. [1]. The former described a 2.3\% prevalence of $P$. vivax $+P$. falciparum infections, while the latter detected $1.34 \%$. More than $99.9 \%$ of the reported Brazilian malaria cases come from this area so, obviously, more asymptomatic cases may occur there as well. How would this data conciliate with the $7.41 \%$ prevalence in São Paulo city and surroundings, as reported by Maselli et al?? What are the ecological conditions in São Paulo State that would sustain such a high rate of asymptomatic $P$. vivax and especially $P$. falciparum infections? The small number of transfusion-transmitted malaria cases (TTM) reported disagrees with the suggested high risk. There are only four cases published from São Paulo State [14-16], all connected to $P$. malariae, while no carrier of this species was reported by Maselli et al. Moreover, the PCR protocol referred by them (Gama et al. ref.\#30) [17] is genus-specific 
whereas the primers employed in their real-time PCR assay are species-specific and most probably taken from the description of Perandin et al. [18], although there are a few nucleotide differences in the FAL-F and VIV-R primers.

It may be argued that the actual contribution of donors included in the "exposed" group to the total blood donors pool from Fundação Pró-Sangue/Hemocentro de São Paulo (FPS) is much less than the approximately $45 \%(500 / 1,108)$ enrolled in the study. This would justify a verified much lower rate of TTM than those numbers would predict. However, in an analysis of 17 spontaneous blood donors from Juquitiba (Atlantic Forest area, São Paulo state, one of the cities that directed donors to the "exposed" group in Maselli's et al. work) that came to FPS, the ELISA using $P$. vivax recombinant antigen (ELISA-Pv) was reagent in $76 \%$ of samples and using $P$. falciparum total extract in 12\%. SD Bioline test using recombinant antigens for both species (SD Bioline $P f / P v$ ) resulted positive in $71 \%$ for $P$. vivax and $0 \%$ for $P$. falciparum. This result points to a cross-reaction with $P$. vivax antibodies using $P$. falciparum total extract. One sample was positive for P. malariae by PCR [19]. Recently, samples of 39 donors from the same area were assayed employing a modified real-time PCR protocol [20] using genus-specific primers [17]. ELISA-Pv was reagent in $38 \%$ of samples and SD Bioline $P f / P v$ was positive in $38 \%$ ( $P v$ band) and $0 \%$ ( $P f$ band). No sample was positive in real-time PCR (data not published).

The PhD thesis linked to this study is freely available [21] and it reports that ELISA was performed with the 84 samples found DNA+. Only eleven out of the 61 samples Plasmodium DNA + from the "exposed" group were seropositive, while none of the 23 from the non-exposed group was positive. This data is not included in the published manuscript. This huge discrepancy was never described in other cohorts. For example, 100\% of blood donors in Nigeria were seropositive for P. falciparum [22], so it remains to be explained why in the São Paulo state cohort, donors that supposedly carry $P$. falciparum or $P$. vivax do not develop detectable antibodies.

The sample size was calculated based on the 1.3\% prevalence of subclinical infection in blood donors in the Amazon region. However, this data is not available in the cited reference (ref.\#3 Ministério da Saúde do Brasil: Sistema de Informação de Vigilância Epidemiológica - Malaria Sivep-Malária; 2010). The authors reported 146 autochthonous cases in 2013 in São Paulo State. In fact, data from Health Ministry registered 16 cases this year and the Health Secretary of São Paulo State informed 13 (provisional data). As the unique reference cited is from 2008 related to data from 1985 to 2006 (Marques et al. ref.\#12), there is doubt about the source of these data. Additionally, the references \#46 and \#47 are improperly cited, since Scuracchio et al. show data from non-endemic area and Fugikaha et al. from endemic region.

\section{Conclusions}

In conclusion, undoubtedly the issue of TTM in São Paulo State deserves further investigation, and certainly, there is an enhanced risk from donors with some epidemiological connection to the forested areas where Plasmodium (mainly P. malariae and P. vivax) persists, since currently there are no active measures to identify such asymptomatic carriers. Unfortunately, the work by Maselli et al., instead of helping in clarifying the size of the risk and potential epidemiological associations in infected donors, brings confusion and unjustified alarm by presenting unrealistic data of donors carrying Plasmodium DNA.

\section{Competing interests}

The authors declare that they have no competing interests.

\section{Authors' contributions}

CCJ and RSM reviewed the entomological aspects of Malaria in the Atlantic Forest. MB and SMDS reviewed the general epidemiology of Plasmodium infections in patients from São Paulo state. MCAS analysed the serological results. AMJ, JEL and VO evaluated the data from blood donors. All authors read and approved the final manuscript.

\section{Acknowledgments}

Acknowledgement of financial support from São Paulo Research Foundation (FAPESP) Grant \# 2014/17828-4.

\section{Author details}

${ }^{1}$ Fundação Pró-Sangue, Hemocentro de São Paulo, São Paulo, Brazil. ¿2Unidade de Medicina Tropical, Universidade Federal do Espírito Santo, Vitoria, Brazil. ${ }^{3}$ Faculdade de Medicina, Universidade de São Paulo, São Paulo, Brazil. ${ }^{4}$ Instituto de Medicina Tropical, Universidade de São Paulo, São Paulo, Brazil. ${ }^{5}$ Superintendência de Controle de Endemias, Secretaria de Estado da Saúde de São Paulo, São Paulo, Brazil.

Received: 25 July 2014 Accepted: 8 August 2014 Published: 28 August 2014

\section{References}

1. Maselli LM, Levy D, Laporta GZ, Monteiro AM, Fukuya LA, Ferreira-da-Cruz MF, Daniel-Ribeiro CT, Dorlhiac-Llacer PE, Sallum MA, Bydlowski SP: Detection of Plasmodium falciparum and Plasmodium vivax subclinical infection in non-endemic region: implications for blood transfusion and malaria epidemiology. Malar J 2014, 13:224

2. Pinotti $M$ : The biological basis for the campaign against the malaria vectors of Brazil. Trans R Soc Trop Med Hyg 1951, 44:663-682.

3. Guimarães $A E$, Gentile C, Lopes CM, Mello RP: Ecology of mosquitoes (Diptera: Culicidae) in areas of Serra do Mar State Park, State of São Paulo, Brazil. II - Habitat distribution. Mem Inst Oswaldo Cruz 2000, 95:753-760.

4. Deane LM, Neto JAF, Okumura M, Ferreira MO: Malaria parasites of Brazilian monkeys. Rev Inst Med Trop Sao Paulo 1969, 11:71-86.

5. Deane LM: Simian Malaria in Brazil. Mem Inst Oswaldo Cruz 1992, 87:1-20.

6. Yamasaki T, Duarte AMRC, Curado I, Summa MEL, Do Valle DDAN, Wunderlich G, Malafronte RS: Detection of etiological agents of malaria in howler monkeys from Atlantic Forests, rescued in regions of São Paulo city, Brazil. J Med Primatol 2011, 40:392-400.

7. Duarte AMRC, Pereira DM, De Paula MB, Fernandes A, Urbinatti PR, Ribeiro AF, Mello MHSH, Matos MO Jr, Mucci LF, Fernandes LN, Natal D, Malafronte RS: Natural infection in anopheline species and its implications for autochthonous malaria in the Atlantic Forest in Brazil. Parasit Vectors 2013, 6:58. 
8. Neves A, Urbinatti PR, Malafronte RS, Fernandes A, Paganini WS, Natal D: Malaria outside the Amazon region: natural Plasmodium infection in anophelines collected near an indigenous village in the Vale do Rio Branco, Itanhaém, SP, Brazil. Acta Trop 2013, 125:102-106.

9. Rezende HR, Soares RM, Cerutti C Jr, Alves IC, Natal D, Urbinatti PR, Yamasaki T, Falqueto A, Malafronte RS: Entomological characterization and natural infection of anophelines in an area of the Atlantic forest with autochthonous malaria cases in mountainous region of Espírito Santo State, Brazil. Neotrop Entomol 2009, 38:272-280.

10. Cerutti C Jr, Boulos M, Coutinho AF, Hatab MCLD, Falqueto A, Rezende HR, Duarte MRC, Collins W, Malafronte RS: Epidemiologic aspects of the malaria transmission cycle in an area of very low incidence in Brazil. Malar J 2007, 6:33.

11. Duarte MRC, Malafronte RS, Cerutti C Jr, Curado I, Paiva BR, Maeda AY, Yamasaki T, Summa MEL, Neves DVDA, Oliveira SG, Gomes AC: Natural Plasmodium infections in Brazilian wild monkeys: Reservoirs for human infections? Acta Trop 2009, 107:179-185.

12. Fugikaha E, Fornazari PA, Penhalbel RSR, Lorenzetti A, Maroso RD, Amoras JT, Saraiva AS, Silva RU, Bonini-Domingos CR, Mattos LC, Rossit ARB, Cavasini CE, Machado RLD: Molecular screening of Plasmodium sp. asymptomatic carriers among transfusion centers from Brazilian Amazon region. Rev Inst Med Trop Sao Paulo 2007, 49:1-4.

13. Batista-dos-Santos S, Raiol M, Santos S, Cunha MG, Ribeiro-dos-Santos A: Real-time PCR diagnosis of Plasmodium vivax among blood donors. Malar J 2012, 11:345.

14. Kirchgatter K, Nogueira SL, Padilha A, Curado I, Boulos M, Di Santi SM: Lethal malaria caused by Plasmodium malariae in an asplenic patient in Brazil. BMJ 2005, 331:576.

15. Di Santi SM, Carvalho ME, Costa MJ, Kirchgatter K, Pereira BF, Toniolo C: Malária transfusional causada por Plasmodium malariae transmitido por doador assintomático infectado na Mata Atlântica do Estado de São Paulo. Rev Soc Brasil Med Trop 2005, 38:333.

16. Scuracchio P, Vieira SD, Dourado DA, Bueno LM, Colella R, Ramos-Sanchez EM, Lima GC, Inoue J, Sanchez MCA, Di Santi SM: Transfusion transmitted malaria: case report of asymptomatic donor harboring Plasmodium malariae. Rev Inst Med Trop Sao Paulo 2011, 53:55-59.

17. Gama BE, Silva-Pires FES, Lopes MNR, Cardoso MAB, Britto C, Torres KL, Lima LM, De Souza JM, Daniel-Ribeiro CT, Ferreira-da-Cruz MF: Real-time PCR versus conventional PCR for malaria parasite detection in low-grade parasitemia. Exp Parasitol 2007, 116:427-432.

18. Perandin F, Manca N, Calderaro A, Piccolo G, Galati L, Ricci L, Medici MC, Arcangeletti MC, Snounou G, Dettori G, Chezzi C: Development of a real-time PCR assay for detection of Plasmodium falciparum, Plasmodium vivax, and Plasmodium ovale for routine clinical diagnosis. I Clin Microbiol 2004, 42:1214-1219.

19. Arroyo Sanchez MC, Lima GFMC, Inoue J, Carvalho ME, Nascimento L, Sanchez AR, Toniolo C, Costa-Nascimento MJ, Di Santi SM: Asymptomatic infections in blood donors harboring Plasmodium detected by molecular and serological tools. Trop Med Int Health 2011, 16:Suppl. I. abstract 1.1-157, pg.145.

20. Lima GFMC, Levi JE, Geraldi MP, Sanchez MCA, Segurado AAC, Hristov AD, Inoue J, Costa-Nascimento MJ, Di Santi SM: Malaria diagnosis from pooled blood samples: comparative analysis of real-time PCR, nested PCR and immunoassay as a platform for the molecular and serological diagnosis of malaria on a large -scale. Mem Inst Oswaldo Cruz 2011, 106:691-700.

21. Validação da triagem clínica para malária em candidatos à doação de sangue (região não-endêmica): University of São Paulo: Aline Maria Monteiro PhD thesis; 2013. www.teses.usp.br/teses/disponiveis/5/5167/tde24032014-111125/pt-br.php.

22. Achidi EA, Perlmann H, Berzins K: Asymptomatic malaria parasitaemia and seroreactivities to Plasmodium falciparum antigens in blood donors from Ibadan, south-western Nigeria. Ann Trop Med Parasitol 1995, 89:601-610.

doi:10.1186/1475-2875-13-336

Cite this article as: Mendrone et al: Unexpected detection of Plasmodium vivax and Plasmodium falciparum DNA in asymptomatic blood donors: fact or artifact? Malaria Journal 2014 13:336.

\section{Submit your next manuscript to BioMed Central and take full advantage of:}

- Convenient online submission

- Thorough peer review

- No space constraints or color figure charges

- Immediate publication on acceptance

- Inclusion in PubMed, CAS, Scopus and Google Scholar

- Research which is freely available for redistribution

Submit your manuscript at www.biomedcentral.com/submit
C Biomed Central 